\title{
Yoğun Bakım Ünitelerinde Çalışan Hemşirelerin Tükenmişlik Düzeyinin Belirlenmesi
}

\section{Determining the Burnout Level of the Nurses Working in Intensive Care Units}

\author{
${ }^{1}$ Dudu KEKEÇ, ${ }^{2}$ Mehtap TAN \\ ${ }^{1}$ Hatay Mustafa Kemal Üniversitesi Dahili Bilimler Hemșiresi, Hatay, Türkiye \\ ${ }^{2}$ Atatürk Üniversitesi Hemşirelik Fakültesi, İç Hastalıkları Hemşireliği Anabilim Dalı, Erzurum, Türkiye
}

Dudu Kekeç: https://orcid.org/0000-0003-4710-0722

Mehtap Tan: https://orcid.org/0000-0001-9994-114X

\begin{abstract}
ÖZ
Amaç: Araştırma Yoğun Bakım Ünitelerinde çalışan hemşirelerin tükenmişlik düzeyinin belirlenmesi amacıyla tanımlayıcı olarak yapılmıştır.

Materyal ve Metot: Araştırma Ocak-Nisan 2014 tarihleri arasında Van Bölge Eğitim ve Araştırma Hastanesi Yoğun Bakım Klinik'lerinde çalışan 90 hemşire ile yapılmıştır. Verilerin toplanmasında; kişisel bilgi formu ve Maslach Tükenmişlik Ölçeği kullanılmıştır. Veriler SPSS 20.0 paket programında değerlendirilmiştir. Verilerin değerlendirilmesinde tanımlayıcı istatistikler, Mann-Whitney U testi ve Kruskal Wallis testi kullanılmıştır.
\end{abstract}

Bulgular: Araştırmaya katılan hemşirelerin \% 80'inin 2029 yaş arasında \%61,2' sinin lisans mezunu, \%83,5'inin yoğun bakımı kendi isteği ile seçtikleri, \%70,6'sının 1-4 yıllık olduğu, \%51,8'inin çalışma ortamından kısmen memnun oldukları, \%38,8'inin iş imkanı olduğu için mesleği seçtikleri bulunmuştur. Ayda tutulan nöbet sayıs1 10 ve üzeri olanlarda, mesleği ilk firsatta değiştireceğim diyenlerde, çalışma ortamından memnun olmayanlarda duygusal tükenme puan ortalamaları ve duyarsızlaşma puan ortalamaları, bekar hemşirelerin ise duyarsızlaşma puan ortalaması yüksek olup aradaki fark istatistiksel olarak anlamlı bulunmuştur $(\mathrm{p}<0,05)$. Hemşirelerin yaşlarına, cinsiyetlerine ve eğitim durumlarına göre MTÖ'nin alt boyutları karşılaştırılmıştır ve anlamlı bir fark bulunmamiştır ( $p>0,05$ ). MTÖ toplam puan ortalaması 46,91 $\pm 8,4$ olarak bulunmuştur. Duygusal tükenmişlik puan ortalamaS1 $19,92 \pm 6,75$, duyarsızlaşma puan ortalaması $6,34 \pm 3,53$, kişisel başarı puan ortalaması $20,77 \pm 4,87$ olarak bulunmuştur.

Sonuç: Çalışma sonuçlarının yoğun bakım ünitesinde çalışan hemşirelerin tükenmişlik durumlarını önlemek için yapılacak girişimlere $1 s ̧ 1 \mathrm{k}$ tutacağı düşünülmektedir.

Anahtar Kelimeler: Hemşire, tükenmişlik, yoğun bakım

\section{ABSTRACT}

Objective: This research was carried out as a descriptive study to determine the burnout level of nurses working in Intensive Care Units (ICUs).

Materials and Methods: The research was conducted with 90 nurses working in Van Regional Training and Research Hospital Intensive Care Clinics between January and April 2014. Data werecollected by personal information survey and Maslach Burnout Inventory (MBI). Data were analyzed using SPSS software 20.0. Mann Whitney $\mathrm{U}$ test and Kruskal Wallis test, as well as descriptive statistics, were utilized in the investigation of data.

Results: Of surveyed nurses, $80 \%$ are $20-29$ years old, $61.2 \%$ graduated from at least a 4-year undergraduate program, $70.6 \%$ have less than $1-4$ years of nursing experience, $51.8 \%$ is partially content with the working environment, $38.8 \%$ chose the nursing career for its higher chance of being employed. The nurses who would switch occupation at the first opportunity and the nurses who works 10 shifts or more in a month have a statistically higher average emotional exhaustion score. The nurses who are not content with their working environment have a statistically higher average emotional exhaustion score and average depersonalization score. The single nurses have a statistically higher average depersonalization score $(p<0.05)$. Age groups, gender, educational status did not have a statistically significant impact on any of MBI's subscales ( $>0.05$ ). The average total MBI score of the population is $46.91 \pm 8.4$, the average emotional exhaustion score is $19.92 \pm 6.75$, the average depersonalization score $6.34 \pm 3.53$, the average personal accomplishment score is $20.77 \pm 4.87$

Conclusion: This research helps provide insight into the burnout status of ICU nurses and shed light on future initiatives to alleviate burnout.

Keywords: Burnout, intensive care unit, nursing

\section{Yayın Bilgisi / Article Info:}

Gönderi Tarihi/ Received: 09/07/2020

Kabul Tarihi/ Accepted: 10/02/2021

Online Yayın Tarihi/ Published: 05/03/2021

Atatürk Üniversitesi Hemşirelik Fakültesi, İç Hastalıkları Hemşireliği Anabilim Dalı, Erzurum, Türkiye

Tel: +05435725582

E-mail: mtan@atauni.edu.tr

Atıf / Cited: Kekeç D, Tan M. Yoğun Bakım Ünitelerinde Çalışan Hemşirelerin Tükenmişlik Düzeyinin Belirlenmesi. Online Türk Sağlık Bilimleri Dergisi 2021;6(1):64-72. doi: 10.26453/otjhs.765237 


\section{GİRIŞ}

Tükenmişlik kavramı ilk olarak tıp dünyasında Helbert Freudenberger tarafindan 1974 yılında tanımlanmış ve kullanılmaya başlanmıştır. ${ }^{1}$ Klinik psikoloğu olan Freudenberger, tükenmişlik kavramını, insanlarla birebir ilişkili olan mesleklerde çalışan bireylerde ve stresli hastalarda psikolojik ve fiziksel yorgunluk, başarısızlık duygusu, hayal kırıklığı ve iş birakmaya kadar gidebilen bir olay olarak ifade etmiştir. $^{2}$

Maslach ise tükenmişlik sendromunu; iş yerindeki uzun süreli strese cevap olarak ortaya çıkan psikolojik bir sendrom olarak tanımlamıştır. ${ }^{3}$

Tükenmişlik sendromu duygusal tükenme, duyarsızlaşma ve kişisel başarı olmak üzere üç boyutta ele alınmaktadır. ${ }^{4}$ Duygusal tükenme; bireyin kendini yaptığı iş nedeniyle aşırı yıpranmış, tüketilmiş olarak hissetmesidir. Duyarsızlaşmada birey başkalarına karşı olumsuz, alaycı tutum ve duygular geliştirir. Tükenmişliğin üç boyutundan olan duyarsızlaşma alt boyutu Maslach'a göre en problemli boyutudur. Kişisel başarı eksikliği, kendini olumsuz değerlendirme, sorunlarla baş etmede yetersizlik olarak tanımlanır. Bireylerde tükenmişlik, duygusal tükenmişlik ve duyarsızlaşmanın artması ve bireysel başarısının düşmesiyle belirlenir. Olumlu birey başarısı ise tükenmişliğin düşük seviyelerini yansıtır. ${ }^{5}$

Tükenmişliğin ne demek olduğu, nasıl ortaya çıktığına ilişkin birçok model geliştirilmiştir. Bunlardan en çok bahsedilenler arasında "Cherniss tükenmişlik modeli", "Maslach tükenmişlik modeli", "Pines tükenmişlik modeli" ve "Edelwich tükenmişlik modeli'dir". 6

Hemşireler, çeşitli faktörlerden dolayı tükenmişlik sendromunu daha fazla yaşamaktadırlar. Bunlar öncelikle işle ilgili olarak yoğun iş yükü, psikososyal problemler, hastanın ani olarak kaybı veya durumunun kötüleşmesi, hasta ve yakınlarına duygusal olarak destek vermek zorunda olmaları, çalıştığı yerin fiziksel özellikleri, işle ilgili karşılaşabileceği tehlikeler (hastalıklar, kimyasal ürünler) olarak sayılabilir. $^{2,7}$

Bütün bu saydıklarımıza ilave olarak yoğun bakım hemşirelerinin, iş yükü daha ağır ve daha fazla sorumlulukları vardır. Yoğun bakım hemşiresi, durumu daha kötü olan hastaya bakım vermek, bakımla ilgili prosedürleri tam olarak yerine getirmek ve acil durumlarda müdahale etmek zorunluluğu ile karşı karşıyadırlar. Bu çalışma koşulları hemşirelerin duygusal kaynaklarının tükenmesine ve tükenmişlik sendromunun oluşmasına yol açmaktadır. ${ }^{8}$
Tükenmişliğe neden olan çevresel faktörler; "çalışma arkadaşları, işin niteliği, çalışılan kurumun tipi, haftalık çalışma süresi, kurumun özellikleri, iş yükü, iş gerilimi, rol belirsizliği, yönetimle ilgili işlerde geçirilen zaman miktarı, önemli kararlara katılmama, örgütsel işleyişteki kusurlar, işin yüksek performans gerektirmesi, hizmet verilen insanlarla ilişkiler, yetersiz personel ve araç, örgütün havası, ortamı, dinlenme zamanlarının azlığı, müşteri gereksinimlerinin finansal ve bürokratik, idari nedenlerle karşılanamaması, kurumun plan ve politikaları, denetim yetersizliği gibi çalışma ortamından kaynaklanan problemleridir". 2,9

Örgütsel tükenmişlik nedenleri; çalışma yerinin mevcut koşulları, beraber çalışılan ekibin ve yapılan işin niteliği ile ilgili tükenmişliğe neden olan faktörlerdir. ${ }^{1,10}$

Araştırma, yoğun bakım ünitesinde çalışan hemşirelerin tükenmişlik düzeyi ve etkileyen faktörleri belirlemek amacıyla yapılmıştır.

\section{MATERYAL VE METOT}

Etik Kurul Onayı: Sağlık Bilimleri Enstitüsü Etik Kuruldan ve araştırmanın yapıldı ğı kurumdan yazılı onay alınmıştır (Tarih: 11.12.2013, karar no: 20135). Araştırmaya katılan hemşirelere araştırmaya yönelik bilgiler verilmiş, araştırmanın amacı anlatılmış ve bilgilendirilmiş onam formu etik bir ilke olarak yerine getirilmiştir. Veri toplama aşamasında Helsinki Bildirgesinde yer alan kurallara uygun olarak hareket edilmiştir.

Araştırma Yoğun Bakım kliniklerinde Ocak-Nisan 2014 tarihleri arasında tanımlayıcı olarak yapılmıştır. Araştırmanın evrenini Van Bölge Eğitim ve Araştırma Hastanesinde yoğun bakım kliniklerinde çalışmakta olan 90 hemşire oluşturmuştur. Araştırmada örneklem seçimine gidilmeyip evrenin tamamı örnekleme alınmıştır. 5 hemşire ön uygulama da kullanılmıştır. Böylece 85 hemşire ile çalışma tamamlanmıştır.

Verilerin toplanmasında hemşirelere ait tanıtıcı bilgileri elde etmek için, tanıtıcı bilgi formu, hemşirelerin tükenmişlik düzeyini belirlemek için Maslach Tükenmişlik Ölçeği kullanılmıştır.

Veriler araştırmanın yapıldı ğı tarihlerde klinikte çalışan hemşirelere anketler araştırmacı tarafından dağıtılarak yüz yüze görüşme yöntemiyle gün içerisinde doldurduktan sonra hemşirelerden geri toplanmıştır. Gece nöbet tutan hemşirelere anketleri araştırmacı tarafından nöbet saatlerinde verilerek toplanmıştır. Tanıtıcı bilgi formu ve ölçeğin doldurulması 
yaklaşık 10-15 dk sürmüştür.

Tanıtıcı Bilgi Formu: $\mathrm{Bu}$ form hemşirelerin yaş, cinsiyet, medeni durumu, eğitim durumu, çalışılan yoğun bakım ünitesi, yoğun bakımı tercih nedeni, yoğun bakımda çalışma süresi, meslekte çalışma süresi, mesleği değiştirme durumu, mesleği isteme durumuyla ilgili bilgileri içeren toplam on sorudan oluşmuştur.

Maslach Tükenmişlik Ölçeği: MTÖ Maslach ve Jackson tarafından tükenmişlik düzeyini ölçmek için oluşturulmuştur. ${ }^{11}$ Duygusal tükenme, duyarsızlaşma ve kişisel başarı düzeyini belirleyici özelliklere sahip 22 maddeden oluşmuştur. Maslach Tükenmişlik Ölçeği, duygusal tükenme, duyarsızlaşma ve kişisel başarı düzeyini belirleyici özelliklere sahip 22 maddeden oluşan 0-5 arasında (0 hiç bir zaman - 5 her zaman) derecelendirilmiş likert tipi bir ölçektir. Duygusal tükenmeye ilişkin 9 soru $(1,2,3,6,8,13$, 14,16 ve 20. sorular), duyarsızlaşmaya ilişkin 5 soru $(5,10,11,15$ ve 22 . sorular), kişisel başarıya ilişkin ise 8 soru $(4,7,9,12,17,18,19$ ve 21 . sorular) bulunmaktadır. Duygusal tükenmeye ilişkin min. 0 max.36 puan; duyarsızlaşmaya ilişkin min. 0 - max. 20 puan; kişisel başarıya ilişkin min. 0 - max. 32 puan alınabilmektedir. Toplamda min. 0, max.88 puana alınabilmektedir. Duygusal tükenme ve duyarsızlaşma puan ortalamasının yüksek, kişisel başarı puan ortalamasının düşük olması bireylerin tükenmişlik yaşadığını göstermektedir. ${ }^{12}$

Türkiye'de ilk kez 1992'de Ergin ${ }^{12}$ tarafından Türkçeye çevrilmiş, geçerlilik ve güvenilirlik çalışması yapılmış olan envanterin 235 kişilik (doktor, hemşire, öğretmen, avukat, polis vb.) bir grupla ön denemesi yapılmış, bu gruptan elde edilen verilerin analizi sonucunda envanterde bazı değişiklikler yapılmıştır. Özgün formu "hiçbir zaman, yılda birkaç kere, ayda bir, ayda birkaç kere, haftada bir, haftada birkaç kere, her gün" şeklinde 7 basamaklı cevap seçeneklerinden oluşmaktadır. Ölçeğin bu özgün biçiminin ülkemize uygun olmadığı belirlenerek, "Hiçbir zaman (0), Çok nadir (1), Bazen (2), Çoğu zaman (3), Her zaman (4)", şeklinde 5 basamaklı cevap seçeneklerine indirilmiştir. $^{12}$

\section{Maslach Tükenmişlik Ölçeği'nin Boyutları}

Duygusal Tükenme: Kişinin duygusal kaynaklarını kendinin hissetmesiyle duygusal bir yoğunluk yaşaması ve çalıştığı kurumda hizmet verdiği kişilere geçmişte olduğu kadar verici ve sorumlu davranmadığını düşünür. Dolayısıyla işe gitmeme, işyerine saatinde gelmeme, psikosomatik şikâyetler nedeniyle işe devamsızlık, işten ayrılma gibi hem çalışan hem de kurum açsından verimsiz bir durum ortaya ç1kmaktadır. $^{12}$

Duyarsızlaşma; Çalışanların hizmet verdikleri kişilere birer nesne gibi davranması, küçültücü sözler sarf etmesi, umursamaz, alaycı bir tutum sergilemesi gözlenmektedir. Kişi kendi içine çekilir, güçlüklerden kaçar ve en az işi yapmaya yönelir. ${ }^{12}$

Kişisel Başarıda Düşme: Kişinin kendisi ile ilgili değerlendirmelerinin olumsuz bir nitelik kazanması sonucu, işle ilgili çeşitli olaylarda kendini yetersiz algılama ve iş yerinde karşılaşılan kişilerle olan ilişkilerde de başarısızlık duygusu baş gösterir. Böylece, harcadığı çabanın boşa gitmesi ve suçluluk duygusu; çalışanın iş motivasyonunu düşürerek gerekli davranışları başarılı bir şekilde gerçekleştirmesini engeller. ${ }^{12}$ Ölçeğin orijinalinde güvenirlik katsayıları duygusal tükenme 0,90; duyarsızlaşma 0,79; kişisel başarı 0,71 . Erginin yaptığı güvenirlik duygusal tükenme 0,83 ; duyarsızlaşma 0,72 ; kişisel başarı 0,67 olarak bulunmuştur. ${ }^{12} \mathrm{Bu}$ çalışma için güvenirlik katsayıları duygusal tükenme 0,80 ; duyarsızlaşma 0,72; kişisel başarı 0,67 olarak bulunmuştur.

Verilerin Değerlendirilmesi: Veriler SPSS (Statistical Package for Social Science) 20.0 paket programında değerlendirilmiştir. Hemşirelerin tanıtıc1 özelliklerine ilişkin veriler, mesleki özelliklerine ilişkin veriler ve Maslach Tükenmişlik Ölçeğine ait veriler SPSS'de yüzdelik, ortalama ve standart sapma ile değerlendirildi. Normal dağılım göstermeyen parametrelerde Kruskal Wallis, Mann Whitney U testi kullanılmıştır. Farklılığa neden olan grubun tespitinde Mann Whitney U testi kullanılmıştır. Anlamlılık $\mathrm{p}<0,01$ ve $\mathrm{p}<0,05$ düzeyinde değerlendirilmiştir.

\section{BULGULAR}

Hemşirelerin \%80'i 20-29 yaş arasında olduğu, \% 61,2' si lisans mezunu, \% 58,8'inin bekar olduğu bulunmuştur. Yoğun bakım ünitesinde çalışan hemşirelerin \%83,5'inin yoğun bakımı kendi istediği ile seçtikleri, \%15,3'ünün nöbet tutmadığı, \%63,5'inin 1-4 yıllık olduğu, \%51,8'inin kısmen çalışma ortamından memnun oldukları, \%38,8'inin iş imkanı olduğu için mesleği seçtikleri, \%57,6'sının koşullar uygun olsa mesleği değiştiririm cevabını verdikleri saptanmıştır.

Çalışmada elde edilen verilere göre duygusal tükenme puan ortalaması $19,92 \pm 6,75$, duyarsızlaşma puan ortalaması $6,34 \pm 3,53$, kişisel başarı puan ortalaması $20,77 \pm 4,87$, toplam puan ortalamas1 $46,91 \pm 8,4$ bulunmuştur (Tablo 1).

Hemşirelerin yaşlarına, cinsiyetlerine ve eğitim durumlarına, çalıştığı birimlere, yoğun bakım tercih 
nedenine, yoğun bakımda çalışma süresine, meslekte çalışma süresine, mesleği isteme durumuna göre MTÖ’nin alt boyutları karşılaştırılmış olup aradaki fark istatistiksel olarak anlamlı bulunmamıştır $(\mathrm{p}>0,05)$. Bekar hemşirelerin duyarsızlaşma puan ortalaması evli olanlardan yüksek olup aradaki fark istatistiksel olarak anlamlı bulunmuştur $(p<0,05)$ (Tablo 2). Ayda 10 ve üzeri nöbet tutanlar ve ilk firsatta mesleği değiştireceğim diyenlerin MTÖ’nin alt gruplarıyla karşılaştırıldığında duygusal tükenme puan ortalamaları yüksek olup aradaki fark istatistiksel olarak anlamlı bulunmuştur $(\mathrm{p}<0,05)$. Çalışma ortamından memnuniyet durumu MTÖ’nin alt gruplarıyla karşılaştırıldığında duygusal tükenme, duyarsızlaşma puan ortalamaları hayır cevabını verenlerde daha yüksektir ve bu fark istatistiksel olarak anlamlı bulunmuştur $(\mathrm{p}<0,05)(\underline{\text { Tablo } 3})$.

\section{TARTIŞMA VE SONUÇ}

Tükenmişlik sendromu, duygusal tükenme ve duyarsızlaşmanın artması, kişisel başarının azalması sonucu ortaya çıkmaktadır. Başkalarına karşı tutum ve davranışların değişmesi, insanlardan uzaklaşma ve sonuç olarak da yalnızlığa yol açan durum duyarsızlaşmadır. ${ }^{12}$ Çalışma sonucunda yoğun bakımda çalışan hemşirelere ait duyarsızlaşma alt boyutu puan ortalaması 6,34 $\pm 3,53$ düşük, duygusal tükenme alt boyutu puan ortalaması 19,92 $\pm 3,53$ normal, kişisel başarı alt boyutu puan ortalaması $20,77 \pm 4,87$ yüksek, toplam puan ortalamas1 $46,91 \pm 8,4$ normalin üzerinde bulundu.

Çalışma sonucunda duyarsızlaşma alt boyutuna ait puan ortalamasının düşük, kişisel başarı alt boyutu puan ortalamasının yüksek olması, toplam puan ortalamasının ortalamadan yüksek olması; hemşirelerin yaşının küçük, yoğun bakımda çalışma sürelerinin kısa olmalarıyla ve yoğun bakımda çalışmayı kendilerinin istemesiyle ilgili olduğu düşünülmüştür. Çalışma sonucunda elde edilen duyarsızlaşma, duygusal tükenme ve toplam tükenmişliğe ait puan ortalamaları, Cerit ve ark.'nın ${ }^{13}$ yoğun bakım hemşireleriyle yapmış oldukları çalışma sonuçları ile benzer bulundu. Şenturan ve ark.'nın, ${ }^{14}$ yaptıkları araştırma sonuçlarıyla da uyumlu bulunmuştur. Çalışmaya katılan hemşirelerin çoğunluğunun genç yaşta olmalarının, yoğun bakımda çalışma sürelerinin az olması ve yoğun bakımda kendi istekleri ile çalışıyor olmalarının sonucu bu yönde etkilemiş olabileceği düşünülmüştür.

Çalışma sonucunda hemşirelerin yaş ile MTÖ’nin alt boyutlarına ait puan ortalamaları arasındaki fark istatistiksel olarak anlamlı $(\mathrm{p}>0,05)$ bulunmamakla beraber yaş arttıkça duyarsızlaşma puan ortalamasının arttığı, kişisel başarının ise düştüğü saptanmıştır. $\mathrm{Bu}$ sonuç yaş arttıkça yoğun iş temposunun hemşirelerde tükenmişliğe yol açabileceğini düşündürmüştür. Kurçer'in, ${ }^{15}$ Palfi ve ark.'nın, ${ }^{16}$ yaptıkları araştırmalarda yaş ile tükenmişlik düzeyi arasında ilişki olmadığını saptamışlardır.

Hemşirelerin cinsiyetlerine ile MTÖ'nin alt boyutlarına ait puan ortalamaları arasındaki fark istatistiksel olarak anlamlı bulunmamıştır ( $>00,05)$. Gökmen'nin, ${ }^{17}$ Akyüz'ün ${ }^{18}$ yaptıkları çalışmaların bulgularında da benzer sonuçlar elde edilmiştir.

Hemşirelerin eğitim durumlarına göre MTÖ’nin alt boyutları karşılaştırılmıştır ve anlamlı bir fark bulunmamıştır $(p>0,05)$. Mollaoğlu ve ark.'nın, ${ }^{19}$ Taycan ve ark.'nın, ${ }^{20}$ ve Tuncel ve ark.'nın, ${ }^{21}$ yaptıkları çalışmada hemşirelerin eğitim düzeyi ve tükenmişlik düzeyi arasında herhangi bir ilişki saptanmamıştır.

Hemşirelerin medeni durumlarına göre MTÖ’nin alt boyutları karşılaştırıldığında, bekar olanların duyarsızlaşma puan ortalaması evlilerin grubunda olanlardan yüksek olduğu aradaki farkın istatistiksel olarak anlamlı olduğu bulunmuştur $(p<0,05)$. Cerit ve ark.'nın ${ }^{13}$ ve Çimen'nin ${ }^{22}$ yapmış oldukları çalışma sonucuyla bu çalışmanın sonucu uyumlu bulunmuştur. Yapılan araştırmalarda evli olmanın tükenmişliği engellediği belirtilmiştir. ${ }^{23,24}$

Ayda tutulan nöbet sayısı MTÖ’nin alt gruplarıyla karşılaştırıldığında 10 ve üzeri nöbet tutanların duygusal tükenme puan ortalamalarının yüksek olduğu ve bu farkın istatistiksel olarak anlamlı olduğu bulunmuştur $(p<0,05)$. Yapılan araştırmalar vardiyalı çalışmanın meslekte stres etkeni olduğu sonucunu ortaya koymaktadır. ${ }^{25}$ Gece ve uzun saat çalışan hemşirelerin fiziksel olarak daha fazla zorlanmalarına ve motivasyonlarının olumsuz etkilenmesine neden olan koşullarda çalışmaları daha hızlı tükenmelerine neden olmaktadır. ${ }^{23}$ Üstün'ün ${ }^{26}$ hemşirelerle yaptığı araştırmada nöbet tutan hemşirelerde duygusal tükenme puanlarının, nöbet tutmayanlara göre anlamlı derecede yüksek olduğu sonucuna varmıştır. Komşuk'un ${ }^{27}$ yapmış olduğu çalışma sonucunda da benzer bulgular bulunmuştur.

Hemşirelerin yoğun bakım tercih nedeni ile MTÖ'nin alt boyutlarına ait puan ortalamaları karş1laştırıldığında aradaki farkın istatistiksel olarak anlamlı olmadığı bulunmakla birlikte yoğun bakımda kendi isteği ile çalışanların duygusal tükenme, duyarsızlaşma puan ortalamaları daha düşük iken kişisel başarı puan ortalamaları yüksek bulunmuştur. Bireyleri istedikleri ve deneyim kazandıkları ünitede çalışması çalışma isteğini ve iş doyumunu arttıracağı 
göz önüne alındığında, çalıştığı birimi isteyerek seçenlerin daha az tükenmişlik duygusu yaşaması beklenen sonuçtur.

Mesleği değiştirme durumu incelendiğinde ilk firsatta değiştireceğim diyenlerin duygusal tükenme puan ortalamasının yüksek olduğu ve bu farkın istatistiksel olarak anlamlı olduğu bulunmuştur $(p<0,05)$. Sayıl ve ark.'nın ${ }^{28}$ yaptığı çalışmada, mesleği değiştirmek isteyenlerin duygusal tükenmişlik yaşadığ sonucuna varmışlardır. Aslan ve ark.'nın, ${ }^{24}$ yaptıkları çalışmalarda mesleği isteyerek yapanların ve değiştirmeyi düşünmeyenlerin tükenmişlik düzeyinin daha az olduğu sonucuna varmışlardır. Mesleği değiştirmek isteyenlerin yaptıkları işten memnun olmamaları nedeniyle huzursuzluk yaşamaları, mesleklerinde kendilerini geliştirmek istememeleri, yoğun bakım gibi çalışma koşulları ağır olan bir birimde çalışanlar için bu durumun beklenen sonuç olduğu düşünülmüştür.

Çalışma ortamından memnuniyet durumu ile MTÖ’nin alt grupları karşılaştırıldığında duygusal tükenme, duyarsızlaşma puan ortalamaları hayır cevabını verenlerde daha yüksek olup aradaki fark istatistiksel olarak anlamlı bulunmuştur $(p<0,05)$. Jourdain $^{29}$ çalışmasında, çalışma ortamından memnuniyet durumunun, mesleki yaşam üzerine etkili bir değişken olacağını belirtmektedir. Çalışma ortamından memnun olmama, birçok nedenle birlikte olup, böyle bir değişkenin tükenmişlik süreci ile ilişkili olabileceğini ifade etmiştir. Sayıl ve ark.'nın ${ }^{28}$ yaptıkları çalışmada iş yerinden kaynaklanan sorunların tükenmişlik yarattığını bulmuşlardır. Yavuz Yılmaz ve ark.'nın ${ }^{30}$ ise yaptıkları çalışmada, çalışma şartlarından memnun olmayanların duygusal tükenmişlik puanının yüksek olduğu sonucuna varmıştır. Bu çalışma sonucunda elde edilen bulgular daha önce yapılan araştırmaların sonuçlarıyla uyumlu bulunmuştur.

Çalışma sonuçlarına göre;Yoğun bakımda çalışan hemşirelerin tükenmişlik durumunu etkileyen faktörlerin belirlenmesi ve bu doğrultuda, üst yönetimin hastanede ki diğer birimlere oranla yoğun bakım da çalışan hemşirelere motivasyon arttırıcı çözümler geliştirmeleri önerilebilir.

Etik Komite Onayı: Çalışma Atatürk Üniversitesi Sağlık Bilimleri Enstitüsü Etik Kuruldan ve araştırmanın yapıldı̆̆ı kurumdan yazılı onay alınmıştır (Tarih: 11.12.2013, karar no: 2013-5).

Çıkar Çatışması: Yazarlar çıkar çatışması bildirmemiştir.
Yazar Katkıları: Fikir - MT, DK; Veri Toplama veya İşleme - DK; Analiz ve/veya yorum - MT, DK; Yazıyı yazan - MT, DK.

Hakem değerlendirmesi: Dış bağımsız.

Teşekkür: Yazarlar, çalışmaya katılan tüm yoğun bakım hemşirelerine teşekkür eder.

\section{KAYNAKLAR}

1. Lacouides A, Fountoulakis K, Moysidov C, Lerodiakonou C. Burnout in nursing staff: A clinical syndrome rather than a psychological reaction? Gen Hosp Psychiatry. 1997;19(6):419428.

2. Demir A. Hemşirelikte tükenmişliğe bir bakış. Atatürk Üniversitesi Hemşirelik Yüksekokulu Dergisi. 2004;7(1):71-80.

3. Maslach C. Job burnout, new directions in research and intervention. APS. 2003;12(5):189192.

4. Yıldırım M.H, İçerli L. Tükenmişlik sendromu: Maslach ve Kopenhag tükenmişlik ölçeklerinin karşılaştırmalı analizi. OYBD. 2010;2(1):123131.

5. Pustulka-Piwnik A, Jan Rynl Z, Krzywoszanski L, Stozek J. Burnout syndrome in physical therapists: demographic and organizational factors. Medycyna Pracy. 2014;65(4):453-462.

6. Beckstead WJ. Confirmatory factor analysis of the maslach burnout inventory among florida nurses. Int J Nurs Stud. 2002;39(8):785-792.

7. Ersoy F, Yıldırım C, Edirne T. Tükenmişlik sendromu. STED. 2005;10(2):1-5.

8. Bakker A, Le Blanc MP, Schaufeli BW. Burnout contagion among intensive care nurses. J Adv Nurs. 2005;51(3):276-287.

9. Piko BF. Burnout, role conflict, job satisfaction and psychosocial health among hungarian health care staff: A questionnaire survey. Int J Nurs Stud. 2006;43(3):311-318.

10. Kocabıyık Z, Çakıcı E. Sağlık çalışanlarında tükenmişlik ve iş doyumu. Anatolian Journal of Psychiatry. 2008;9(2):132-138.

11. Maslach J, Jackson SE. The measurement of experienced burnout. J Occup Behav. 1981;2:99113.

12. Ergin C. Doktor ve hemşirelerde tükenmişlik ve Maslach tükenmişlik ölçeğinin uyarlanması. VII.Ulusal Psikoloji Kongresi Bilimsel Çalışmaları, Ankara, Türk Psikologlar Derneği Yayını; 1997:143-154.

13. Cerit GN, Aykal G, Güzel A, Kara İ. Bir hastanede çalışan yoğun bakım hemşirelerinde tüken- 
mişlik düzeyinin belirlenmesi. Anadolu Kliniği. 2016;1(2):25-30.

14. Şenturan, L, Karabacak B. Sabuncu, N. Hemodiyaliz ünitelerinde çalışan hemşirelerin tükenmişlik düzeyi. Maltepe Üniversitesi Hemşirelik Bilim ve Sanatı Dergisi. 2009;2(2):22-24.

15. Kurçer MA. Harran Üniversitesi Tıp Fakültesi hekimlerinin iş doyumu ve tükenmişlik düzeyleri. H.Ü. Tip Fak Dergisi. 2005;68(1):29-32.

16. Palfi I, Nemeth K, Kerekes Z, Kallai J, Bethelem $\mathrm{J}$. The role of burnout among hungarian nurses. Int J Nurs Pract. 2008;14(1):9-25.

17. Gökmen V. Yoğun bakım ünitelerinde çalışan hemşirelerin iş doyumları, tükenmişlik ve kaygı düzeylerinin incelenmesi. Atatürk Üniversitesi Cerrahi Anabilim Dalı. Yüksek Lisans Tezi. Erzurum, Türkiye. 2013.

18. Akyüz İ. Hemşirelerin tükenmişlik ve depresyon düzeylerinin çalışma koşulları ve demografik özellikler açısından incelenmesi. İşletme ve İktisat Çalışmaları Dergisi. 2015;3(1):21-34.

19. Mollaoğlu M, Yılmaz M, Kars T. Hemşirelerde tükenmişlik sendromu. Toplum ve Hekim Dergisi. 2003;18(4):288-293.

20. Taycan O, Kutlu L, Çimen S, Aydın N. Bir üniversite hastanesinde çalışan hemşirelerde depresyon ve tükenmişlik düzeyinin sosyodemografik özelliklerle ilişkisi. Anatolian Journal of Psychiatry. 2006;7(2):100-108.

21. Tunçel Y.İ, Kaya M, Kuru R.N, Menteş S, Ünver S. Onkoloji hastanesi yoğun bakım ünitesinde hemşirelerin tükenmişlik sendromu. Türk Yoğun Bakım Derneği Dergisi. 2014;12(2):57-62.

22. Çimen M, Ergin C. Türk Silahlı Kuvvetleri sağlık personelinin tükenmişlik düzeylerinin incelenmesi. Gülhane Tip Dergisi. 2001;43 (2):169-176

23. Şahin D, Turan FN, Alparslan N, Şahin İ, Faikoğlu R, Görgülü A. Devlet hastanesinde çal1şan sağlık personelinin tükenmişlik düzeyleri. Nöropsikiyatri Arşivi. 2008;45(4):116-121.

24. Aslan S, Coşkun H, Alpaslan S, Nazan Z. Bakırköy ruh ve sinir hastalıları hastanesinde çalışan hemşirelerde tükenme, işe bağlı gerginlik, a-tipi kişilik ve mükemmelcilik. Cukurova Medical Journal. 2000;25(3):27-35.

25. Demir A. Hemşirelerin çalışma ortamlarında stres oluşturan faktörlerin irdelenmesi. Toplum ve Hekim. 2003;18(6):23-27.

26. Üstün B. Hemşirelerin atılganlık ve tükenmişlik düzeyleri. Hacettepe Üniversitesi Sağlık Bilim- leri Enstitüsü. Doktora Tezi. Ankara, Türkiye.1995.

27. Komşuk D. Ameliyathanede çalışan hemşirelerde, uyku sorunlarının tükenmişlik düzeyine etkisinin incelenmesi. Osmangazi Üniversitesi Cerrahi Hastalıkları Hemşireliği Anabilim Dalı.Yüksek Lisans Tezi. Eskişehir, Türkiye. 2013.

28. Sayıl I, Haran S, Ölmez Ş, Özgüven Devrimci H. Ankara Üniversitesi hastanelerinde çalışan doktor ve hemşirelerin tükenmişlik düzeyleri. Kriz Dergisi. 2010;5(2):71-77.

29. Jourdain G, Chenevert D. Job demandsresources, burnout and intention to leave the nursing profession: A questionnaire survey. Int $\mathrm{J}$ Nurs Stud. 2010;47(6):709-722.

30. Yavuzyılmaz A, Topbaş M, Çan E, Çan G, Özgün Ü. Trabzon il merkezindeki sağlık ocakların çalışanlarında tükenmişlik sendromu ile iş doyumu düzeyleri ve ilişkili faktörler. TSK Koruyucu Hekimlik Bülteni. 2007;6(1):41-50. 
Tablo 1. Hemşirelerin tükenmişlik ölçeği toplam ve ölçek alt boyutlarına ait puan ortalamalarının dağı̆lımı.

\begin{tabular}{|l|c|c|}
\hline Tükenmişliğin Alt Boyutları & Min - Max & $\mathbf{X} \pm$ SD \\
\hline Duygusal Tükenme & $0-36$ & $19,92 \pm 6,75$ \\
\hline Duyarsızlaşma & $0-20$ & $6,34 \pm 3,53$ \\
\hline Kişisel Başarı & $0-32$ & $20,77 \pm 4,87$ \\
\hline Toplam Puan Ortalaması & $0-88$ & $46,91 \pm 8,4$ \\
\hline
\end{tabular}


Tablo 2. Hemşirelerin tanıtıcı özellikleri ile tükenmişlik alt boyutlarına ait puan ortalamalarının karşılaştırılması.

\begin{tabular}{|c|c|c|c|}
\hline $\begin{array}{c}\text { Tanitıcı } \\
\text { Özellikler }\end{array}$ & $\begin{array}{c}\text { Duygusal } \\
\text { Tükenme } \\
\mathrm{X} \pm \mathrm{SD} \\
\end{array}$ & $\begin{array}{c}\text { Duyarsızlaşma } \\
\text { X } \pm \text { SD }\end{array}$ & $\begin{array}{c}\text { Kişisel Başarı } \\
\mathbf{X} \pm \text { SD }\end{array}$ \\
\hline \multicolumn{4}{|l|}{ Yaş } \\
\hline $20-29$ & $20,32 \pm 6,6$ & $6,64 \pm 3,70$ & $20,77 \pm 4,75$ \\
\hline $30-39$ & $18,13 \pm 7,14$ & $5,06 \pm 2,68$ & $21,20 \pm 5,72$ \\
\hline \multirow[t]{2}{*}{$40-49$} & $14,00 \pm 0,0$ & $7,00 \pm 0,0$ & $16,00 \pm 0,0$ \\
\hline & $\begin{array}{c}\mathrm{KW}: 3,178 \\
\mathrm{p}>0,05\end{array}$ & $\begin{array}{c}\mathrm{KW}: 2,39 \\
\mathrm{p}>0,05\end{array}$ & $\begin{array}{c}\mathrm{KW}: 1,690 \\
\mathrm{p}>0,05\end{array}$ \\
\hline \multicolumn{4}{|l|}{ Cinsiyet } \\
\hline Kadın & $19,86 \pm 6,10$ & $6,69 \pm 3,47$ & $20,44 \pm 4,09$ \\
\hline \multirow[t]{2}{*}{ Erkek } & $20,07 \pm 8,16$ & $5,61 \pm 3,64$ & $21,53 \pm 6,33$ \\
\hline & $\begin{array}{c}\text { MWU:725 } \\
\mathrm{p}>0,05\end{array}$ & $\begin{array}{c}\text { MWU:633 } \\
p>0,05\end{array}$ & $\begin{array}{c}\text { MWU:757 } \\
p>0,05\end{array}$ \\
\hline \multicolumn{4}{|c|}{ Eğitim durumu } \\
\hline $\begin{array}{l}\text { Sağlik mes- } \\
\text { lek lisesi }\end{array}$ & $21,04 \pm 6,93$ & $7,14 \pm 4,06$ & $21,38 \pm 4,36$ \\
\hline Ön lisans & $19,60 \pm 6,39$ & $5,00 \pm 3,68$ & $22,40 \pm 4,24$ \\
\hline Lisans & $19,38 \pm 6,86$ & $6,42 \pm 3,28$ & $20,32 \pm 5,19$ \\
\hline \multirow[t]{2}{*}{$\begin{array}{l}\text { Yüksek } \\
\text { lisans }\end{array}$} & $24,00 \pm 4,24$ & $3,50 \pm 0,70$ & $18,00 \pm 4,24$ \\
\hline & $\begin{array}{c}\mathrm{KW}: 1,583 \\
\mathrm{p}>0,05\end{array}$ & $\begin{array}{c}\mathrm{KW}: 4,429 \\
\mathrm{p}>0,05\end{array}$ & $\begin{array}{c}\mathrm{KW}: 2,591 \\
\mathrm{p}>0,05\end{array}$ \\
\hline \multicolumn{4}{|c|}{ Medeni durum } \\
\hline Evli & $19,48 \pm 6,52$ & $5,37 \pm 2,64$ & $21,20 \pm 4,96$ \\
\hline \multirow[t]{2}{*}{ Bekar } & $20,24 \pm 6,95$ & $7,063,92$ & $20,48 \pm 4,84$ \\
\hline & $\begin{array}{c}\text { MWU:84 } \\
p>0,05\end{array}$ & $\begin{array}{c}\text { MWU:647 } \\
\text { p }<0,001\end{array}$ & $\begin{array}{c}\text { MWU:824 } \\
p>0,05\end{array}$ \\
\hline
\end{tabular}


Tablo 3. Hemşirelerin mesleki özellikleri ile tükenmişlik alt boyutlarına ait puan ortalamalarının karşılaştırılması.

\begin{tabular}{|c|c|c|c|}
\hline Mesleki Özellikler & $\begin{array}{c}\text { Duygusal Tükenme } \\
\text { X } \pm \text { SD }\end{array}$ & $\begin{array}{c}\text { Duyarsızlaşma } \\
\mathbf{X} \pm \text { SD }\end{array}$ & $\begin{array}{c}\text { Kişisel Başarı } \\
\text { X } \pm \text { SDD }\end{array}$ \\
\hline \multicolumn{4}{|c|}{ Yoğun bakımı tercih nedeni } \\
\hline Kendi isteğimle & $19,63 \pm 6,72$ & $6,22 \pm 3,56$ & $21,16 \pm 4,86$ \\
\hline \multirow[t]{2}{*}{ İdarenin isteğiyle } & $21,42 \pm 6,96$ & $7,07 \pm 3,45$ & $18,78 \pm 4,59$ \\
\hline & $\begin{array}{l}\text { MWU:450 } \\
\mathrm{p}>0,05\end{array}$ & $\begin{array}{c}\text { MWU:429 } \\
\mathrm{p}>0,05\end{array}$ & $\begin{array}{c}\text { MWU:343 } \\
p>0,05\end{array}$ \\
\hline \multicolumn{4}{|l|}{ Aylık tutulan nöbet sayısı } \\
\hline $1-5$ & $19,00 \pm 9,00$ & $5,76 \pm 4,04$ & $17,00 \pm 5,00$ \\
\hline $6-9$ & $18,79 \pm 5,95$ & $6,04 \pm 3,77$ & $21,11 \pm 5,19$ \\
\hline 10 ve üzeri & $23,28 \pm 6,87$ & $7,52 \pm 3,44$ & $20,88 \pm 4,36$ \\
\hline \multirow[t]{2}{*}{ Nöbet tutmuyorum } & $17,53 \pm 7,05$ & $5,38 \pm 2,43$ & $20,30 \pm 4,85$ \\
\hline & $\begin{array}{c}\text { KW:8,209 } \\
\mathbf{p}<0,05\end{array}$ & $\begin{array}{c}\mathrm{KW}: 5,044 \\
\mathrm{p}>0,05\end{array}$ & $\begin{array}{c}\mathrm{KW}: 1,679 \\
\mathrm{p}>0,05\end{array}$ \\
\hline \multicolumn{4}{|c|}{ Yoğun bakımda çalışma süresi } \\
\hline 1 y1ldan az & $21,30 \pm 6,11$ & $6,61 \pm 3,27$ & $19,23 \pm 5,18$ \\
\hline $1-4$ & $20,23 \pm 7,04$ & $6,51 \pm 3,78$ & $20,70 \pm 4,54$ \\
\hline $5-9$ & $16,22 \pm 5,33$ & $5,66 \pm 2,39$ & $21,55 \pm 5,87$ \\
\hline $10-14$ & $19,00 \pm 8,48$ & $5,50 \pm 2,12$ & $26,50 \pm 6,36$ \\
\hline \multirow[t]{2}{*}{15 ve üzeri } & $19,00 \pm 0,00$ & $2,00 \pm 0,00$ & $27,00 \pm 0,00$ \\
\hline & $\begin{array}{c}\mathrm{KW}: 3,175 \\
\mathrm{p}>0,05\end{array}$ & $\begin{array}{c}\mathrm{KW}: 2,416 \\
\mathrm{p}>0,05\end{array}$ & $\begin{array}{c}\mathrm{KW}: 4,906 \\
\mathrm{p}>0,05\end{array}$ \\
\hline \multicolumn{4}{|c|}{ Çalışma ortamından memnuniyet durumu } \\
\hline Evet & $17,30 \pm 6,64$ & $5,34 \pm 2,65$ & $20,91 \pm 5,96$ \\
\hline Hayır & $25,33 \pm 5,78$ & $9,11 \pm 3,47$ & $18,50 \pm 3,82$ \\
\hline \multirow[t]{2}{*}{ Kismen } & $19,09 \pm 6,05$ & $5,77 \pm 3,46$ & $21,63 \pm 4,42$ \\
\hline & $\begin{array}{c}\mathrm{KW}: 14,796 \\
\mathbf{p}<0,001\end{array}$ & $\begin{array}{c}\text { KW:13,052 } \\
\mathbf{p}<0,001\end{array}$ & $\begin{array}{c}\mathrm{KW}: 5,482 \\
\mathrm{p}>0,05\end{array}$ \\
\hline \multicolumn{4}{|l|}{ Mesleği Değiştirme Durumu } \\
\hline $\begin{array}{l}\text { Koşullar uygun olsa de- } \\
\text { ğiştiririm }\end{array}$ & $20,83 \pm 6,31$ & $6,75 \pm 3,53$ & $20,97 \pm 4,75$ \\
\hline İlk firsatta değiştireceğim & $24,71 \pm 5,06$ & $7,35 \pm 3,77$ & $18,21 \pm 4,50$ \\
\hline $\begin{array}{l}\text { Yapabildiğim kadar sür- } \\
\text { düreceğim }\end{array}$ & $14,82 \pm 6,03$ & $4,50 \pm 2,85$ & $22,22 \pm 5,36$ \\
\hline \multirow[t]{2}{*}{$\begin{array}{l}\text { Emekliliğe kadar sürdüre- } \\
\text { ceğim }\end{array}$} & $15,00 \pm 3,74$ & $6,50 \pm 3,87$ & $20,75 \pm 4,87$ \\
\hline & $\begin{array}{c}\text { KW:19,774 } \\
\mathbf{p}<0,001\end{array}$ & $\begin{array}{c}\mathrm{KW}: 7,417 \\
\mathrm{p}>0,05\end{array}$ & $\begin{array}{c}\mathrm{KW}: 4,733 \\
\mathrm{p}>0,05\end{array}$ \\
\hline \multicolumn{4}{|l|}{ Mesleği isteme durumu } \\
\hline Ailemin isteğiyle & $20,33 \pm 7,07$ & $7,38 \pm 3,55$ & $20,77 \pm 5,20$ \\
\hline İş imkanı olduğu için & $20,72 \pm 6,70$ & $6,27 \pm 3,03$ & $20,87 \pm 5,06$ \\
\hline Çevrenin etkisiyle & $21,00 \pm 2,51$ & $5,71 \pm 2,56$ & $21,85 \pm 4,77$ \\
\hline \multirow[t]{2}{*}{ Kendi isteğimle } & $18,40 \pm 7,36$ & $5,96 \pm 4,28$ & $20,37 \pm 4,67$ \\
\hline & $\begin{array}{c}\mathrm{KW}: 1,859 \\
\mathrm{p}>0,05\end{array}$ & $\begin{array}{c}\mathrm{KW}: 2,071 \\
\mathrm{p}>0,05\end{array}$ & $\begin{array}{c}\mathrm{KW}: 0,333 \\
\mathrm{p}>0,05\end{array}$ \\
\hline
\end{tabular}

